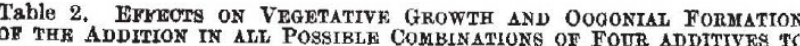
A FORTIFIED BASAL MIDDIUM

(Data listed are averages of triplicate determinations per treatment)

\begin{tabular}{|c|c|c|c|}
\hline \multirow{2}{*}{ Fortifled basal modium plus: } & \multicolumn{2}{|c|}{ Mycelium weight (mg) } & No. of oogonis \\
\hline & 6 days & & 21 days \\
\hline $\begin{array}{l}X-\text { no additive control } \\
\text { Mo-molyblenum }\end{array}$ & 73 & 77 & $313-I \S$ \\
\hline Cu-copper $\uparrow$ & $\begin{array}{l}59 \\
55\end{array}$ & $\begin{array}{l}78 \\
80\end{array}$ & $0_{0}^{\theta-1}$ \\
\hline $\mathrm{Mn}$-manganese $\dagger$ & 58 & 03 & 0 \\
\hline Zn-zinef & 58 & 64 & 0 \\
\hline $\mathrm{Cu}, \mathrm{Mo}$ & 67 & 83 & 10 \\
\hline Mn, Mo & 70 & 93 & $713-M$ \\
\hline $\operatorname{Mn}, \mathrm{Cu}$ & 56 & 90 & 0 \\
\hline $\mathrm{Zn}, \mathrm{Mo}$ & 65 & 61 & 0 \\
\hline $\mathrm{Zn}, \mathrm{Cu}$ & 66 & $6 \overline{0}$ & 0 \\
\hline $\mathrm{Zn}, \mathrm{Mn}$ & 104 & $8 B$ & $3,047-M$ \\
\hline $\mathrm{Mn}, \mathrm{Cn}, \mathrm{Mo}$ & 52 & 90 & 0 \\
\hline $\mathrm{Zn}, \mathrm{Cu}, \mathrm{Mo}$ & B1 & 60 & 0 \\
\hline $\mathrm{Zn}, \mathrm{Mn}, \mathrm{Mo}$ & 107 & 80 & $2,990-M$ \\
\hline $\mathrm{Zn}, \mathrm{Mn}, \mathrm{Cu}$ & 100 & 85 & $3,570-M$ \\
\hline $\mathrm{Zn}, \mathrm{Mn}, \mathrm{Cu}, \mathrm{Mo}$ & 104 & 87 & $3,483-M$ \\
\hline H.S.D. levels $\ddagger<05$ & $\begin{array}{l}13 \\
15\end{array}$ & 6 & 717 \\
\hline
\end{tabular}

* Basal medium fortifled with cholesterol, thiamine, calcium, and iron a concentrations listed in Table 1 .

t Added at the concentrations and in the salt forms listed in Table 1.

$\ddagger$ Honestly significant test between any two means (method of Tukey (ref. 4)) at the 1 per cent and 5 jer cent confldence-levels.

$\S I$, Immature; $M$, mature.

and 6-day mycelial weights than any of the media not containing both of these metals. The control and the manganese-molybdenum treatment are the only modia which produced an appreciable number of oogonia without having both zine and manganese present. By factorial arialysis, both the latter metals were found to produce highly significant main factor effects. For vegetative growth, zine had the greatcst stimulatory effect; on interaction the effects of zinc and manganese tended to bo additive. Copper and molybdenum showed no significant main factor effocts. However, copper interacted significantly with the other three metals to inhibit vegetative growth, although it showed no effect on oogonial formation. As for tho provious experiment, the 21-day mycelial weight results were not interpreted because of extensive autolysis

Fothergill and Hides, working with four other species of Pythium, found that calcium, iron, trace minerals and thiamine had no effect on growth (no sterol was present). We found that all theso additives stimulated the growth of $P$. graminicola, whether tested with our basal medium or with the media of Fothergill and Hide. This differenco is undoubtedly attributable to a difference in the requiremonts of the species and isolates employed. Similarly, we found that Pythium vexans and $P$. arrhenomanes producod oogonia on Czapek's medium plus sterol, in the absence of zinc, manganese and calcium ${ }^{3}$. In addition to this, Hendrix ${ }^{2}$ found that sterols induced sexual reproduction in Pythium periplocum and Phytophthora magasperma, although his basic medium contained no zinc, manganese or calcium. It is apparent that some species of Pythium have much more exacting metal ion requirements for reproduction and growth than do other species.

J AMES F. LENNEY

Prcific Biomedical Research Centor,

GOWARD W. KUEMMER

Univorsity of Hawaii, Honolulu.

Haskins, R. H., Tulloch, A. P., and Micetich, R. G., Canad. J. Microbiol. 10, 187 (1964)

'Hendrix, J. W., Science, 144, 1028 (1964).

${ }^{3}$ Klemmer, H. W., and Lenney, J. F., Phytopathology, 55, 820 (1905)。

" Tukey, J. W. in Experimental Design, edit. by Federer, W. 'I'. (The Macmillan Co., Now York, 1955).

s Fothergill, P. G., and Hide, D., J. Gen. Microbiol., 29, 325 (1962).

\section{Protandrous Hermaphroditism in Decapod Prawns of the Families Hippolytidae and Campylonotidae}

PROTANDROUS hermaphroditism, or the changing from the male sex to the female during the growth of the same individual, is now well known in certain northern-hemi- sphere commercial prawns of the family Pandalidae, namely, species of tho genera Pandalus $\left(P\right.$. borealis ${ }^{1}$, $P$. danae ${ }^{1}, P$. hypsinotus ${ }^{1}, P$. kessler $i^{2}, P$. montagui $i^{3}$ and $P$. platyceros ${ }^{1}$ ) and Pandalopsis $\left(P\right.$. dispar $\left.{ }^{1}\right)$. In the Hippolytidae, this phenomenon has been demonstrated in two European and Mediterranean species of Lysmata, namoly, $L$. seticaudata (the first decapod in which protandry was recognized ${ }^{4}$ ) and $L$. nilita ${ }^{5}$.

In 1959, Carlisle ${ }^{8}$ summarized our knowledge of sex reversal in decapods, discussing the aforementioned groups and adding the burrowing axiid Oalocaris macandreae. The latter, however, has since been shown ${ }^{7}$ not to be a protandrous hermaphrodite, but a functional hermaphrodite throughout life. Recently I recognized protandry in the Australasian, archibenthal slope species Campylonotus rathbunae Schmitt and discussed tho changes in secondary scxual characters involved ${ }^{8}$. A partially sympatric pandalid, now known as Notopandalus magnoculus (Bate), is not a protandrous hermaphrodite. Another specics in the southern, monogeneric family Campylonotidae, the Magellanic C. semistriatus Bate, was also shown to be protandrous from a re-examination of the Challenger type material in the British Museum (Natural History).

Protandry can now be recorded in the Magellanic and Antarctic hippolytid Chorismus antarcticus (Pfeffor). A collection taken at Isla Navarino off the southern coast of Tierra del Fuego during the Royal Society Darwin Memorial Expedition to Southern Chile, 1958-59, consisted of males of carapace lengths 6.5-10 mm with a well-developed appendix masculina on the second pleopod, intersex spccimens of $10-10.5 \mathrm{~mm}$ with a vestigial appendix masculina and females of $12-13 \mathrm{~mm}$ with no trace of this appendix.

It was also considered likely that the Indian Ocoan and Australasian subantaretic hippolytid, Nauticaris marionis Bate, would prove to be protandrous. Preliminary examination of recent collections from Auckland and Campbell Islands in the New Zealand subantarctic, and from deep water off southern New Zealand, revealed that all the large specimens were female, mostly ovigerous, while the smaller specimens were largely male. Detailed examination, however, showed males with a woll-developed appendix masculina of carapace lengths $4 \cdot 5-7.5 \mathrm{~mm}$, no recognizable intersex specimens and females of earapace lengths 4.5-11.5 mm. This specics, then, does not show sex reversal, but mature females do reach a much larger size than males.

Protandrous hermaphroditism in decapod Crustacen appears to be restricted, so far as our knowledge goes, to two genera of northern borcal and temperate pandalids, two Mediterranean species of the hippolytid Lysmata, the antiboreal South Amorican and circum-Antaretic hippolytid Chorismus and at least two species of the antiboreal South American and dcep-water Australasian palaemonoid Campylonotus. The three families represented are not closely related systemically, each presently being placed in a different super-family ${ }^{9}$, and besides the rather tenuous zoogeographic relationships (? analogous to bipolarity) no link, other than that of reproductive physiology, can be seen.

\section{J. C. YALDWYN}

The Australian Museum, Sydney,

New South Wales.

${ }^{1}$ Berkeley, Alfreda A., Contr. Canad. Biol. Fish., N.S., 6 (6), 79 (1930),

${ }^{2}$ Aoto, T., J. Fac. Sci. Holkaido Univ., Ser. 6 (Zool.), 2, 1 (1952).

Allen, J. A., J. Mar. Biol. Axsoc, U.K., 43 (3), 881 (1983).

4 Spitschakoff, T., Z, wiss, Zool, 100, 190 (1912).

s Dohrn, P. F. R., and Holthuis, L. B., Pubbl. Staz. Zool. Napoli, 22 (3), 889 (1950).

- Carlisle, D. B., .T. Mar. Biol. Assoc. T.K., 38 (3), 494 (1959).

'Buchanan, J. B., J. Mar. Biol. Assoc. U.K., 43 (3), 720 (1903).

8 Yaldwyn, J. C., N.Z. Dept. Sci. Indust. Res, Isull., 139 (1), 24 (1060).

${ }^{\prime}$ Hosthuis, L. B., Zool. Verhand. Leiden, 26, 1 (1955). 